\title{
ANALISIS LAJU TIMBULAN SAMPAH DI PULAU PRAMUKA DKI JAKARTA
}

\author{
Siti Rohana Nasution, AR. Indra Tjahjani \\ Universitas Pancasila Fakultas Teknik \\ e-mail: sitirohananasution@gmail.com; arindratjahjani@gmail.com
}

\begin{abstract}
ABSTRAK
Pengelolaan sampah dari rumah tangga telah menarik perhatian beberapa stakeholder seperti pemerintah, bisnis, lembaga swadaya masyarakat dan konsumen. Di Kepulauan Seribu khususnya di Pulau Pramuka menghadapi tantangan besar dalam pengelolaan sampah. Praktek-praktek yang terkait dengan pembongkaran, daur ulang dan pembuangannya, serta kurangnya kesadaran masyarakat terhadap potensi risiko yang terkait dengan manajemen yang kurang patut dipraktekkan dari aliran limbah ini. Dalam situasi ini, prosedur dan praktek yang melibatkan pengumpulan, pembongkaran, daur ulang dan pembuangan sampah dari rumah tangga perlu diinvestigasi, dengan tujuan menciptakan sistem manajemen sampah yang lebih berkelanjutan di kepulauan seribu khusunya Pulau Pramuka. Penelitian ini mengindentifikasi potensi kepedulian dan kemampuan masyarakat yang tercermin dari sikap dan perilaku dalam berkontribusi terhadap pengelolaan sampah. Penelitian ini menggunakan metode penggabungan dari disiplin ilmu teknik dan ilmu sosial guna mendapatkan data subyektif dan obyektif dari lokasi penelitian. Hasil dari studi didapat besarnya laju timbulan sampah di pulau pramuka dari studi ini dapat memberikan informasi dan strategi yang dapat direkomendasikan bagi Dinas Lingkungan Hidup Pemerintah Pulau Pramuka khususnya P. Pramuka dalam kaitannya sistem manajemen sampah yang berkelanjutan.
\end{abstract}

Kata kunci: timbulan sampah, pengelolaan sampah, sikap dan perilaku masyarakat.

\section{ABSTRACT}

Waste management from households has attracted the attention of several stakeholders such as government, business, non-governmental organizations and consumers. In the Thousand Islands, especially in Pramuka Island faces major challenges in waste management. Practices related to demolition, recycling and disposal, as well as a lack of public awareness of the potential risks associated with management that are not worth practicing from this waste stream. In this situation, procedures and practices involving the collection, dismantling, recycling and disposal of garbage from households need to be investigated, with the aim of creating a more sustainable waste management system in the thousand islands especially Pramuka Island. This research identified the potential of community care and ability as reflected in attitudes and behaviors in contributing to waste management. This study uses a merging method from technical disciplines and social sciences to obtain subjective and objective data from the research location. The results of the study found that the rate of solid waste generation at Scout Island from this study can provide information and strategies that can be recommended for the Environmental Agency of Pramuka Island Government especially $P$. Pramuka in relation to a sustainable waste management system.

Keywords: waste generation, waste management, community attitudes and behavior.

\section{PENDAHULUAN}

Permasalahan sampah timbul akibat pengelolaan sampah yang tidak dilakukan dengan baik. Sistem pengumpulan yang tidak tuntas, kurangnya alat angkut dan terbatasnya kapasitas tempat pembuangan akhir sampah (TPA) menurut Pramono. Hal ini menjadi permasalahan yang khas mencakup aspek teknis, sosial dan budaya. Pengetahuan dan kepedulian masyarakat untuk memilah sampah sangat rendah karena pola kebiasaan dan perilaku masyarakat yang terbiasa membuang sampah tanpa memperhatikan komposisi dari sampah tersebut. Kondisi sampah yang tercampur ini sangat menyulitkan bagi pemerintah dan dinas kebersihan dalam melakukan daur ulang. Banyak material yang seharusnya dapat didaur ulang tetapi pada akhirnya hanya ditimbun di TPA. 
Wilayah Kabupaten Administrasi Kepulauan Seribu terletak di sebelah Utara Teluk Jakarta dan Laut Jawa Jakarta. Wilayah ini termasuk ke dalam Provinsi DKI Jakarta. Lokasinya berada antara $06^{\circ} 00^{\prime} 40^{\prime \prime}$ dan $05^{\circ} 54^{\prime} 40^{\prime \prime}$ Lintang Selatan serta 106 $40^{\prime} 45^{\prime \prime}$ dan 10901'19" Bujur Timur. Luas daratan Kabupaten Administrasi Kepulauan Seribu 864,59 Ha $(8,76 \mathrm{Km} 2)$ dan luas perairan mencapai $474.562 \mathrm{Ha}(4.745,62 \mathrm{Km} 2)$. Jumlah keseluruhan pulau yang ada di wilayah Kabupaten Administrasi Kepulauan Seribu mencapai 110 buah dengan 11 pulau diantaranya merupakan pulau pemukiman. Dari 110 buah pulau yang ada, empat pulau diantaranya telah tenggelam yaitu Pulau Dapur, Pulau Nyamuk Besar, Pulau Ubi Besar dan Pulau Ubi Kecil. Pulau Untung Jawa merupakan pulau berpenghuni yang terletak paling selatan (paling dekat dengan Jakarta) sedangkan pulau yang terletak paling utara adalah Pulau Sebira dengan jarak sekitar 150 Km dari Jakarta.

Penelitian ini dipandu oleh beberapa pertanyaan:

a. Karakteristik apa saja dan berapa potensi sampah yang dapat dihasilkan oleh rumah tangga di Pulau Pramuka

b. Bagaimanakah metode pengumpulan, daur ulang dan pembuangan sampah.

c. Bagaimana peran serta masyarakat dalam memberikan kontribusi pengelolaan sampah di Pulau Pramuka

\section{Tujuan dari Penelitian ini adalah:}

a. Mengetahui karakteristik dan potensi laju timbulan sampah yang ada di masyarakat di Pulau Pramuka.

b. Mengevaluasi metode yang ada pengumpulan, daur ulang dan pembuangan sampah di Pulau Pramuka.

c. Mengkaji peran serta masyarakat dalam memberikan kontribusi pengelolaan sampah di Pulau Pramuka.

\section{LANDASAN TEORI}

\section{Timbulan Sampah}

Timbulan sampah adalah volume sampah atau berat sampah yang di hasilkan dari jenis sumber sampah diwilayah tertentu persatuan waktu (Departemen PU, 2004). Timbulan sampah adalah sampah yang dihasilkan dari sumber sampah (SNI, 1995). Timbulan sampah sangat diperlukan untuk menentukan dan mendesain peralatan yang digunakan dalam transportasi sampah, fasilitas recovery material, dan fasilitas Lokasi Pembuangan Akhir (LPA) sampah. menurut SNI 19-3964-1995, bila pengamatan lapangan belum tersedia, maka untuk menghitung besaran sistem, dapat digunakan angka timbulan sampah sebagai berikut:

1) Satuan timbulan sampah kota sedang $2,75-3,25 \mathrm{~L} / \mathrm{orang} / \mathrm{hari}$ atau $0,070-0,080 \mathrm{~kg} /$ orang/hari.

2) Satuan Timbulan sampah kota kecil $=2,5-2,75 \mathrm{~L} / \mathrm{orang} / \mathrm{hari}$ atau $0,625-0,70 \mathrm{~kg} / \mathrm{orang} /$ hari

Keterangan:

Untuk kota sedang jumlah penduduk $100.000<\mathrm{p}<500.000$.

Untuk kota kecil jumlah penduduk $<100.000$.

Prakiraan timbulan sampah baik untuk saat sekarang maupun dimasa mendatang merupakan dasar dari perencanaan, perancangan dan pengkajian sistem pengelolaan persampahan. Prakiraan timbulan sampah merupakan langkah awal yang biasa dilakukan dalam pengelolaan persampahan. Satuan timbulan sampah biasanya dinyatakan sebagai 
satuan skala kuantitas perorang atau perunit bangunan dan sebagainya. Rata-rata timbulan sampah tidak akan sama antara satu daerah dengan daerah lainnya, atau suatu negara dengan negara lainnya. Hal ini disebabkan oleh beberapa faktor, antara lain [1]:

1) Jumlah penduduk dan tingkat pertumbuhannya.

2) Tingkat hidup.

3) Perbedaan musim.

4) Cara hidup dan mobilitas penduduk.

5) Iklim.

6) Cara penanganan makanannya.

\section{Sumber Sampah}

Sumber-Sumber Sampah

1) sampah buangan rumah tangga.

2) sampah buangan pasar dan tempat-tempat umum (warung, toko, dan sebagainya)

3) sampah buangan jalanan

4) sampah industri termaksud diantaranya air limbah industri, debu industri. Sisa bahan baku dan bahan jadi dan sebagainya [2]

5) Sampah yang berasal dari perkantoran. Umumnya sampah ini bersifat kering dan mudah terbakar (rabbish).

6) Sampah yang berasal dari pertanian atau perkebunan.

7) Sampah yang berasal dari pertambangan

8) Sampah yang berasal dari peternakan dan perikanan

\section{Menurut Sifat Fisiknya}

1) Sampah kering yaitu sampah yag dapat dimusnahkan dengan dibakar

2) Sampah basah yaitu sampah yang karena sifat fisiknya sukar dikeringkan untuk dibakar [2].

\section{Jenis Sampah}

Sampah dibedakan atas sifat biologisnya sehingga memperoleh pengelolaan yakni, sampah yang dapat membusuk, seperti (sisa makan, daun, sampah kebun, pertanian, dan lainnya), sampah yang berupa debu, sampah yang berbahaya terhadap kesehatan, seperti sampa-sampah yang berasal dari industri yang mengandung zat-zat kimia maupun zat fisik berbahaya [3].

Sedangkan menurut Amos Noelaka sampah dibagi menjadi 3 bagian yakni [4]:

\section{Sampah Organik}

Sampah Organik merupakan barang yang dianggap sudah tidak terpakai dan dibuang oleh pemilik/pemakai sebelumnya, tetapi masih bisa dipakai, dikelola dan dimanfaatkan dengan prosedur yang benar.

\section{Sampah Non-organik}

Sampah non-organik adalah sampah yang dihasilkan dari bahan-bahan non hayati, baik berupa produk sintetik maupun hasil proses teknologi pengolahan bahan tambang. Sampah jenis ini pada tingkat rumah tangga misalnya botol plastik, botol gelas, tas plastik, dan kaleng [5].

\section{Sampah B3 (Bahan berbahaya beracun)}

Pada sampah berbahaya atau bahan beracun (B3), sampah ini terjadi dari zat kimia organik dan nonorganik serta logam-logam berat, yang umunnya berasal dari buangan industri. Pengelolaan sampah B3 tidak dapat dicampurkan dengan sampah organik dan 
nonorganik. Biasanya ada badan khusus yang dibentuk untuk mengelola sampah B3 sesuai peraturan berlaku.

\section{Karakteristik Sampah}

Karakteristik sampah terbagi atas beberapa aspek yakni sebagai berikut:

1) Sampah Basah (Garbage) adalah jenis sampah yang terdiri dari sisa sisa potongan hewan atau sayur-sayuran hasil dari pengolahan, pembuatan dan penyediaan makanan yang sebagian besar terdiri dari zat-zat yang mudah menbusuk.

2) Sampah Kering (Rubbish) adalah sampah yang dapat terbakar dan tidak dapat terbakar yang berasal dari rumah-rumah, pusat-pusat perdangangan, kantor-kantor.

3) Abu (Ashes) adalah sampah yang berasal dari sisa pembakaran dari zat yang mudah terbakar seperti rumah, kantor maupun dipabrik-pabrik industri.

4) Sampah Jalanan (Street Sweping) adalah sampah yang berasal dari pembersihan jalan dan trotoar baik dengan tenaga manusia maupun dengan tenaga mesin yang terdiri dari kertas kertas, dedaun daunan dan lain-lain.

5) Bangkai binatang (Dead animal) adalah jenis sampah berupa sampah-sampah biologis yang berasal dari bangkai binatang yang mati karena alam, penyakit atau kecelakaan.

6) Sampah rumah tangga (Household refuse) merupakan sampah campuran yang terdiri dari rubbish, garbage, ashes yang berasal dari daerah perumahan.

7) Bangkai kendaraan (Abandonded vehicles) adalah sampah yang berasal dari bangkaibangkai mobil, truk, kereta api.

8) Sampah industri merupakan sampah padat yang berasal dari industri- industri pengolahan hasil bumi/tumbuh-tubuhan dan industri lain

9) Sampah pembangunan (Demolotion waste) yaitu sampah dari proses pembangunan gedung, rumah dan sebagainya, yang berupa puing-puing, potongan-potongan kayu, besi beton, bambu dan sebagainya [6].

10) Sampah khusus adalah jenis sampah yang memerlukan penanganan khusus misalnya kaleng cat, flim bekas, zat radioaktif dan lain-lain [7].

\section{Faktor-Faktor yang Mempengaruhi Masalah Sampah}

Sampah, baik kuantitas maupun kualitasnya sangat dipengaruhi oleh berbagai kegiatan dan taraf hidup masyarakat. Beberapa faktor penting yang mempengaruhi sampah antara lain:

1) Jumlah penduduk. Dapat dipahami dengan mudah bahwa semakin banyak penduduk, semakin banyak pula sampahnya.

2) Keadaan sosial ekonomi. Semakin tinggi keadaan sosial ekonomi masyarakat, semakin banyak pula jumlah per kapita sampah yang dibuang tiap harinya.

3 ) Kemajuan teknologi. Kemajuan teknologi akan menambah jumlah maupun kualitas sampah, karena pemakaian bahan baku yang semakin beragam, cara pengepakan dan

4 ) produk manufaktur yang semakin beragam dapat mempengaruhi jumlah dan jenis sampahnya

\section{METODOLOGI PENELITIAN}

Berikut merupakan gambar diagram alir kegiatan penelitian ini. 


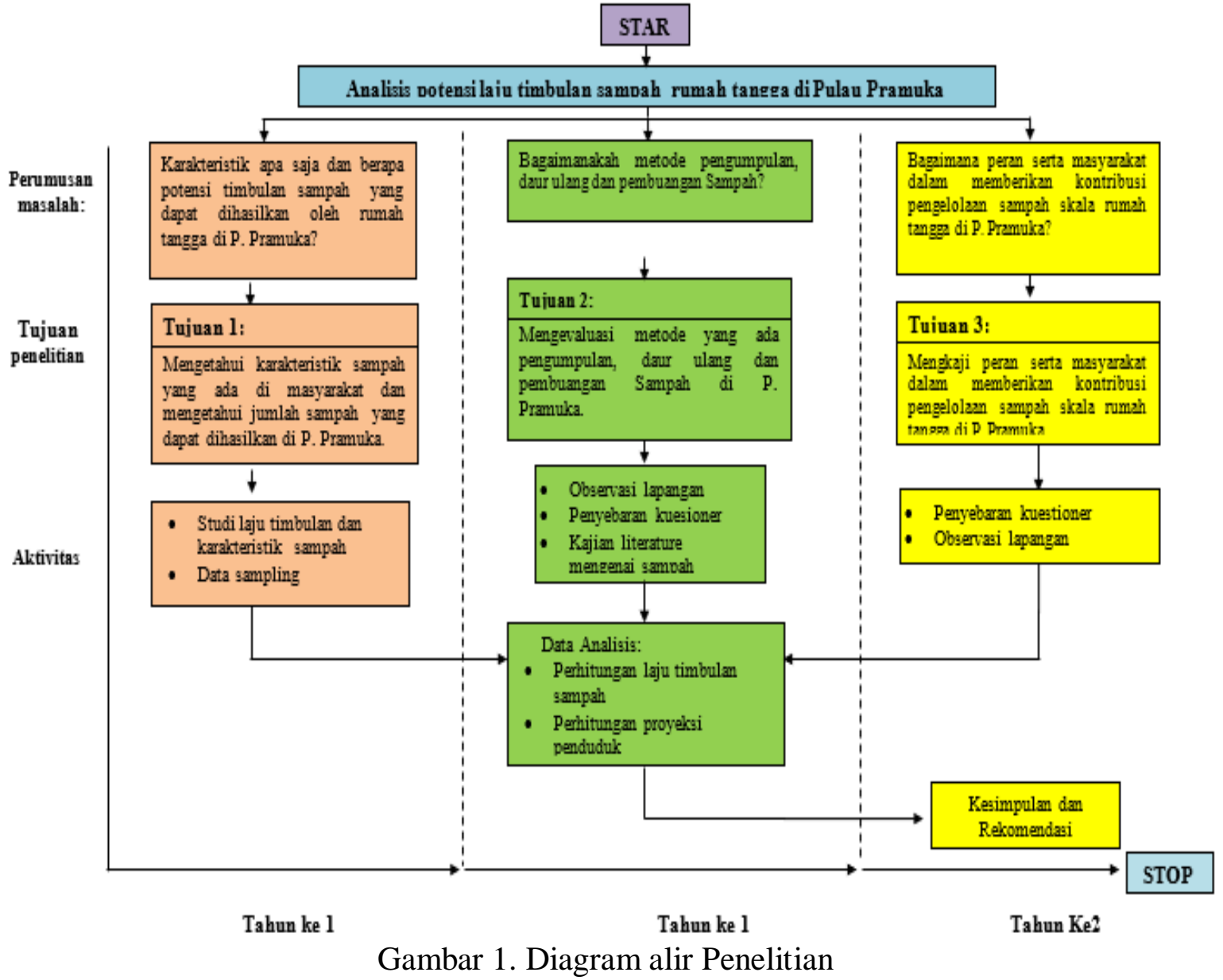

\section{Pengumpulan data}

Pengumpulan data dilakukan dengan mencari data primer dan sekunder.

Data disajikan dalam Tabel 1, Tabel 2 dan Tabel 3.

Tabel 1. Komposisi sampah di Pulau Pramuka

\begin{tabular}{|c|c|c|}
\hline \multirow{2}{*}{$\begin{array}{c}\text { Jenis Sampah yang } \\
\text { Dihasilkan }\end{array}$} & \multicolumn{2}{|c|}{ Berat $(\mathrm{Kg})$ dan Persentase (\%) } \\
\hline & Rata-rata (kg) & $(\%)$ \\
\hline \multicolumn{3}{|l|}{ Organik } \\
\hline - Compostable & 11,91 & 58,6 \\
\hline - Uncompostable & 0,46 & 2,30 \\
\hline \multicolumn{3}{|l|}{ Anorganik } \\
\hline - Plastik & 3,99 & 19,6 \\
\hline - Kertas & 2,21 & 10,9 \\
\hline - Logam & 0,48 & 2,40 \\
\hline - Kaca & 0,69 & 3,40 \\
\hline - Kain & 0,49 & 2,40 \\
\hline - Karet & 0,10 & 0,50 \\
\hline Total & 20,33 & 100 \\
\hline
\end{tabular}

Tabel 2. Jumlah Penduduk Pulau Pramuka

\begin{tabular}{cc}
\hline Tahun & Jumlah Penduduk \\
\hline 2011 & 942 \\
2012 & 1.064 \\
2013 & 1.203 \\
2014 & 1.359 \\
2015 & 1.536 \\
2016 & 1.736 \\
2017 & 2.048 \\
\hline
\end{tabular}


Tabel 3. Komponen dan Komposisi Sampah P Pramuka

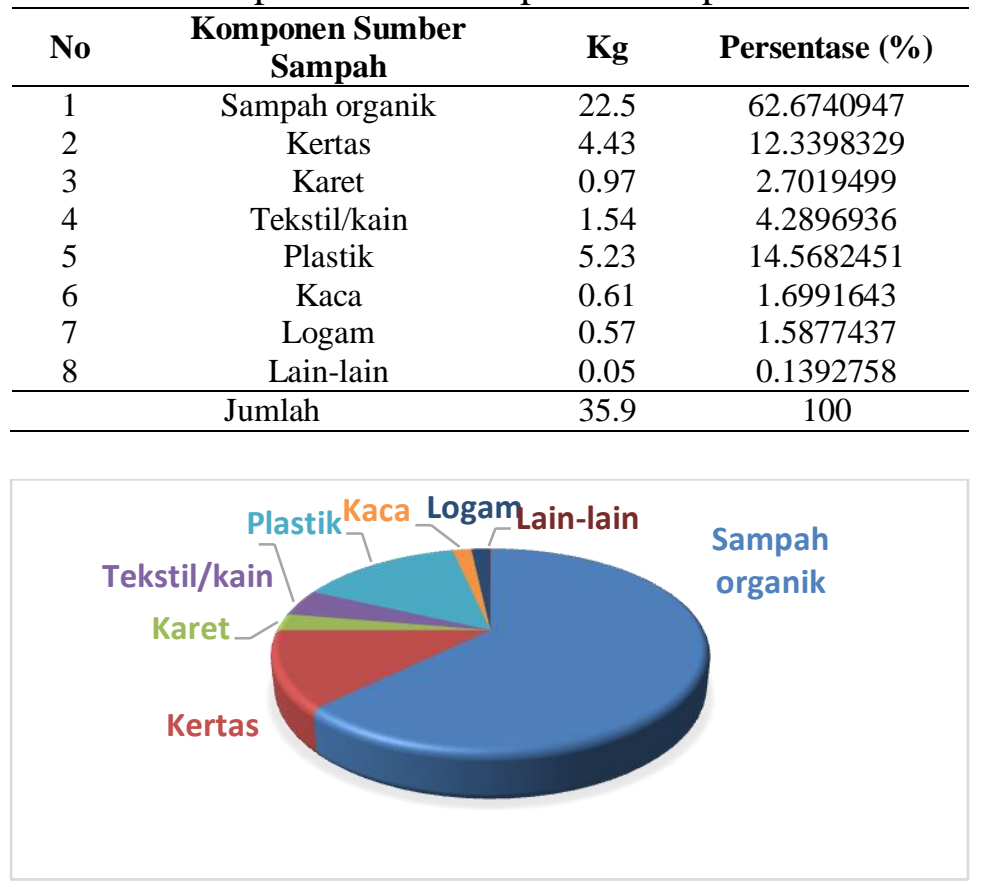

Gambar 2. Komponen dan Komposisi Sampah

\section{HASIL DAN PEMBAHASAN}

\section{Pengelolaan sampah di RW 04 Pulau Pramuka}

\section{Pewadahan}

Masyarakat Pulau Pramuka di RW 04 dan RW 05 mewadahi sampah rumah tangga mereka ke wadah yang disediakan mandiri, dan sebagian wadah diperoleh bantuan dari LMK dan Pemerintah. Masyarakat Pulau Pramuka jarang melakukan pemilahan sampah organik dan anorganik walaupun ada beberapa tempat disediakan untuk pembagian sampah tetapi pada kenyataanya sampah masih tercampur.

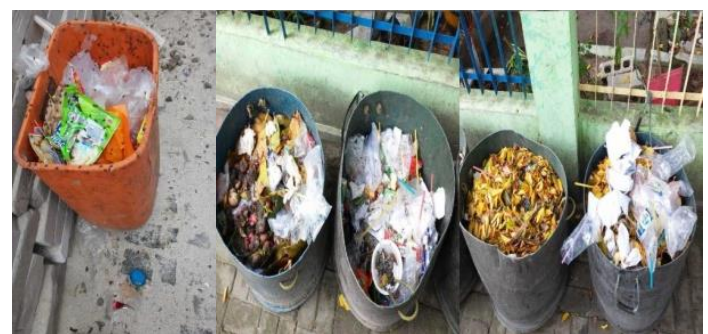

Gambar 3. Tempat Sampah Warga

\section{Pemrosesan}

Beberapa warga yang mempunyai keahlian dalam membuat kerajinan tangan dari sampah, melakukan pemrosesan dengan jalan membuat tas, dompet dari sampah plastik. Sampah plastik yang dianggap bias digunkan untuk membuat kerajinan tangan dipisahkan dengan sampah lain.

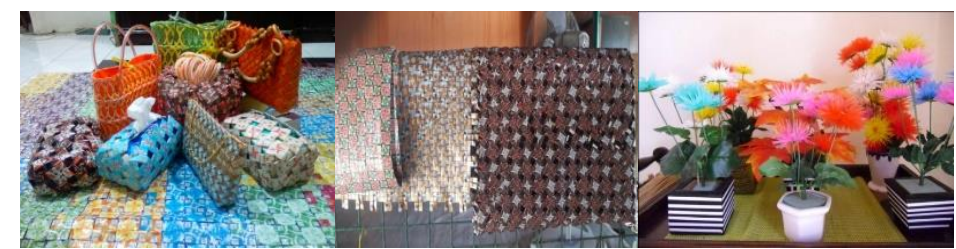

Gambar 4. Hasil Kerajian Tangan 

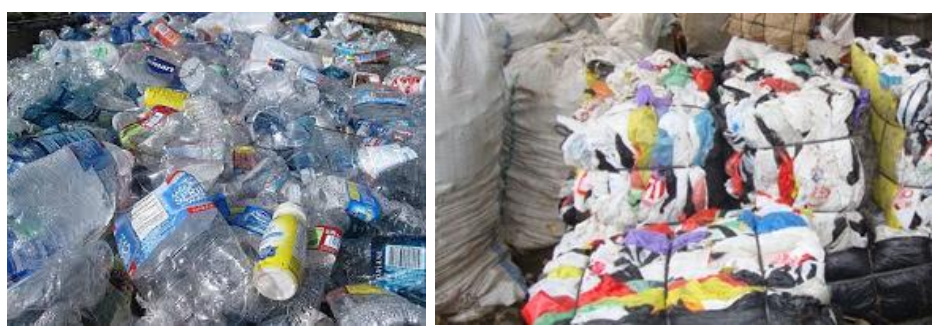

Gambar 5. Sampah yang siap dijual Lapak Tempat Penjualan sampah

Ada juga beberapa warga yang melakukan composting dan sudah dilakukan pelatihan oleh Suku Dinas Ketahanan Pangan Kelautan dan Pertanian Kepulauan Seribu yang melatih warga yang tergabung dalam kelompok Percepatan Penganekaragaman Konsumsi Pangan (P2KP) mengenai cara membuat kompos organik (composting) di Rumah Hijau Pulau Pramuka, Kepulauan Seribu Utara.

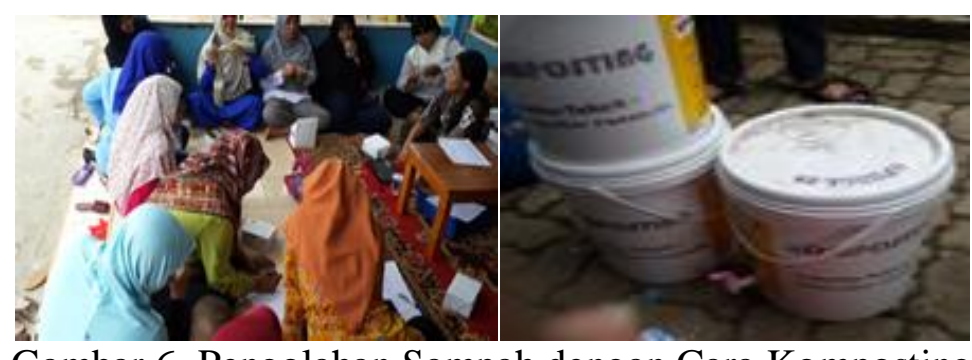

Gambar 6. Pengolahan Sampah dengan Cara Komposting

\section{Pengumpulan/Pemindahan}

Sebelum diangkut dan dikumpulkan ke lokasi pembuangan sampah, maka sampah yang sudah diwadahi diangkut oleh petugas sampah dikumpulkan di Lokasi Pembuangan sampah (LPS) dengan menggunakan gerobak sampah. Semenjak tahun 2012 Pengelolaan sampah dilakukan oleh masyarakat secara individu.

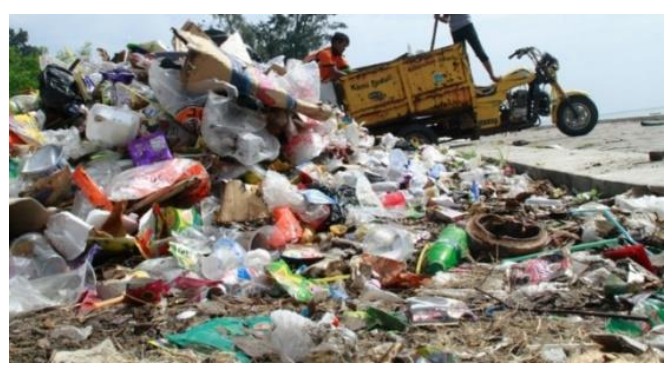

Gambar 7. Pengelolaan Sampah

\section{Pemusnahan}

Sebagian besar masyarakat memusnahkan sampah dengan jalan di timbun begitu saja atau dibakar.
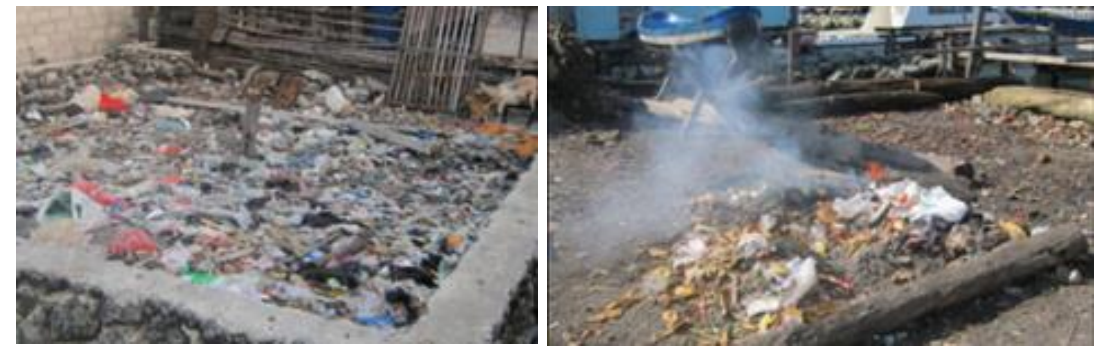

Gambar 8. Pemusnahan sampah dengan di timbun 


\section{Masalah sampah di RW 04 dan RW O5 Pulau Pramuka}

Dari hasil wawancara kelompok terfokus terhadap tokoh masyarakat dan ibu rumah tangga yang ada di RW 04 dan RW05 di Pulau Pramuka terkait dengan masalah sampah adalah sebanyak kurang lebih 70-80\% sampah tidak berakhir di lokasi pembuangan sampah tetapi di sekitar pemukiman warga dan di laut.
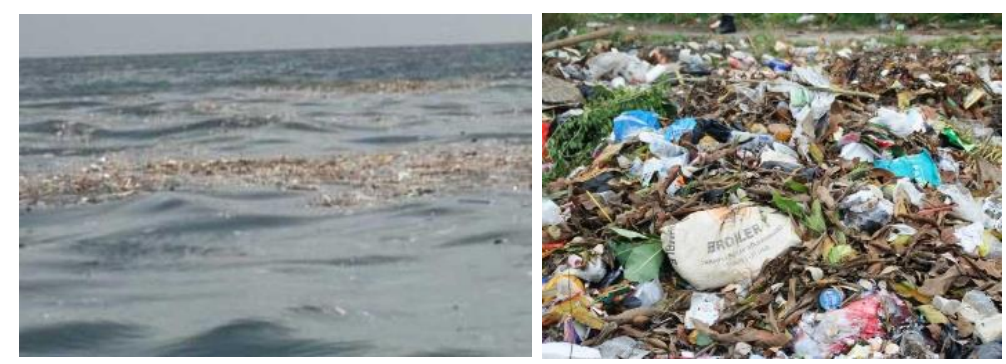

Gambar 9. Sampah yang berakhir di laut dan Sampah yang berakhir di Lokasi Pembuangan Sampah
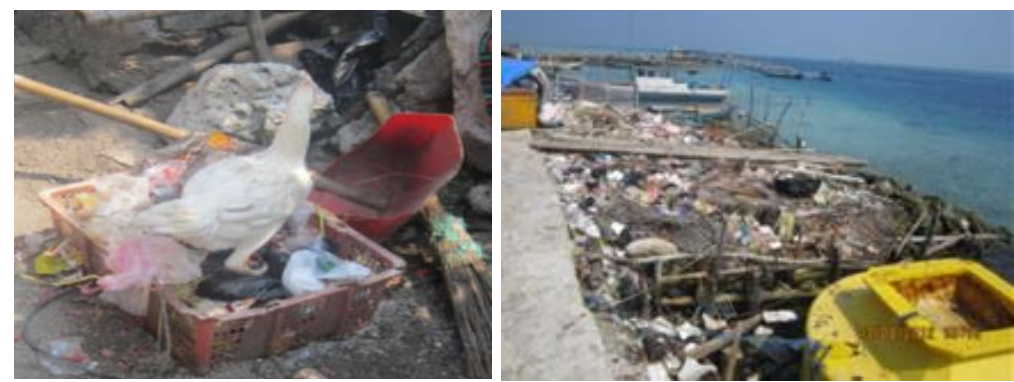

Gambar 10. Tempat pewadahan sampah masyarakat RW 04 dan Sampah yang dibuang keurukan
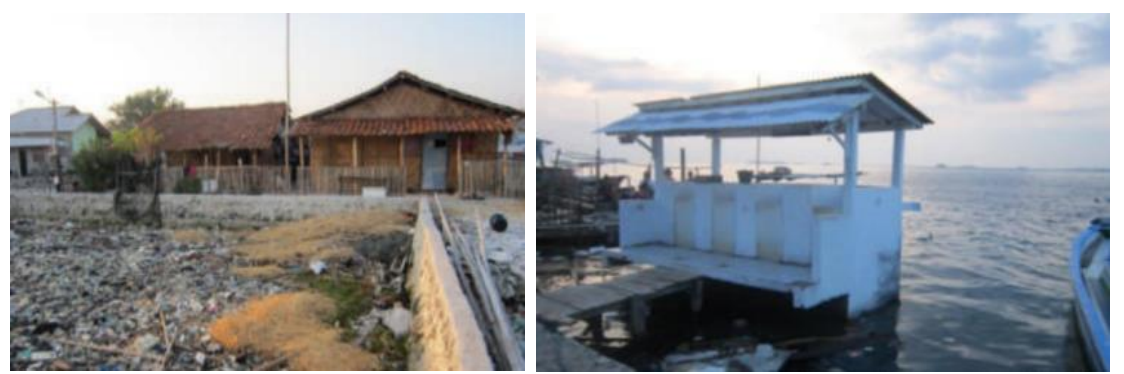

Gambar 11. Sampah yang dibuang ke LPS dan Sampah yang dibuang ke laut

Sebanyak 85\% sampah rumah tangga masyarakat RW 04 dan 05 Pulau Pramuka pada Tahun 2017 tidak berakhir di Lokasi Pembuangan Sampah (LPS), tetapi di sekitar pemukiman warga dan di laut dengan asumsi bahwa 1 Kepala Keluarga setiap harinya menghasilkan sampah sebanyak 1 ember atau 1 jerigen.

\section{Faktor Manusia dan Sosial yang Mempengaruhi Permasalah Sampah}

\section{Perilaku membuang sampah}

Tabel 4. Perilaku masyarakat membuang sampah

\begin{tabular}{lc}
\hline \multicolumn{1}{c}{ Perilaku } & Prosentase \\
\hline Membuang Sampah Ke urukan & $75 \%$ \\
Membuang sampah ke LPS & $15 \%$ \\
Membuang sampah ke laut & $5 \%$ \\
Memanfaatkan sampah & $5 \%$ \\
\hline
\end{tabular}




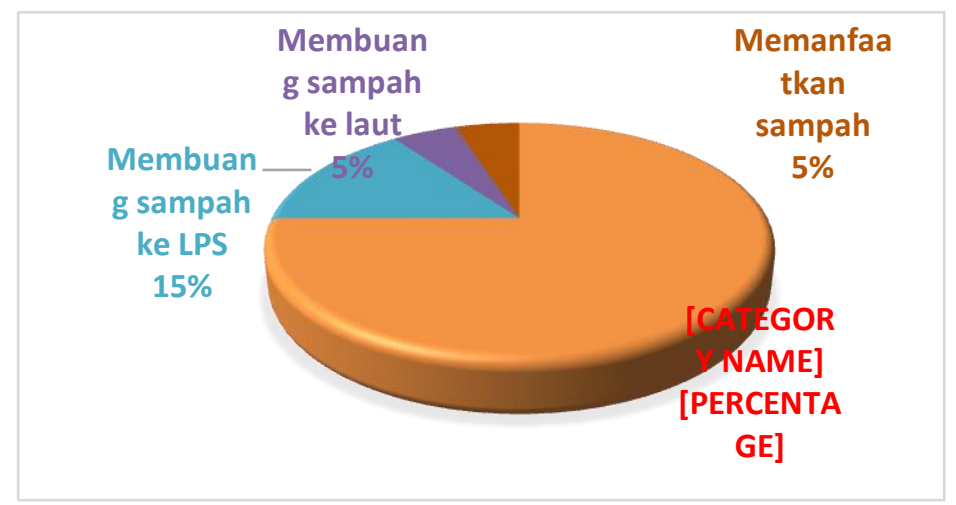

Gambar 12. Perilaku Membuang Sampah

\section{Predisposisi}

a. Masyarakat memandang bahwa pemerintah (RT, RW terumata kelurahan) yang bertanggungjawab terhadap masalah sampah, terutama untuk membayar petugas sampah. Mereka menganggap pemerintah terutama kelurahan memiliki dana untuk hal ini.

b. Belum adanya kerjasama yang kuat antar RT, RW, LMK dan kelurahan untuk menggerakkan masyarakat terlihat dari jawaban reponden meraa keberatan untuk dana pengelolaan sampah.

c. Modal sosial: berkembang sebuah norma di masyarakat bahwa dalam setiap acara/ kegiatan/program pasti ada imbalannya dalam bentuk tunia atau dikonversi dalam bentuk lain.

\section{Faktor Non Manusia}

\section{Finansial}

Tidak diberikannya lagi anggaran dari kelurahan untuk gaji petugas sampah membuat petugas sampah tidak mengangkut sampah warga ke LPS lagi. Sementara masyarakat keberatan untuk membayar iuran untuk sampah, kecuali mereka yang memiliki warung. Hal ini karena penghasilan masyarakat, yang sebagian besar nelayan, tidak menentu.

\section{Teknologi}

Tidak termanfaatkannya mesin pembakar sampah/incinerator yang ada di Pulau Pramuka karena rusak dan tidak ada operator yang menjalankan.

\section{Lingkungan}

Banyak masyarakat yang mereklamasi (menguruk) pantai dengan batu dan sampah untuk tempat tinggal mereka, membuat luas wilayah Pulau Pramuka secara umum terus bertambah. Kondisi ini karena masyarakat lebih senang tinggal berdekatan dengan keluarga mereka dan ditambah harga tanah untuk rumah yang menurut mereka mahal dibanding mereka menguruk pantai.

\section{Regulasi Kebijakan dan Program Mempengaruhi Masalah Sampah}

1. Seringnya program-program atau kegiatan-kegiatan yang melibatkan masyarakat Pulau Pramuka membiasakan memberikan uang atau amplop ke masyarakat. Hal ini berdampak pada berkembangnya faktor modal sosial di masyarakat sebagaimana sudah dijelaskan sebelumnya.

2. Masih adanya progam tentang sampah yang berorientasi proyek sehingga berampak pada modal teknologi yang tidak termanfaatkan. 
3. Belum adanya program pengelolaan sampah secara menyeluruh dan terpadu. Masingmasing pihak melakukan program mereka sendiri sendiri: yang satu melakukan sosialisasi yang lain melakukan pelatihan dan yang lainnya lagi kerja bakti bersama. Satu dan yang lainnya tidak terkoordinasi untuk mencapai tujuan bersama (mengatasi masalah sampah)

4. Regulasi dan Kebijakan:

a) Sistem demokrasi kita yang sudah sampai pada tingkat yang paling bawah (RT/RW) tidak bisa dikontrol dengan baik sehingga menimbulkan praktek politik uang di setiap pemilihan langsung. Ini menyebabkan masyarakat Pulau Pramuka telah diajarkan untuk bertindak berdasarkan berapa jumlah uang yang diperoleh.

b) Penghapusan Sudin Kebersihan Kab. Kepulauan Seribu

Analisis Laju Timbulan Sampah di Pulau Pramuka berdasarkan data jumlah penduduk dan dari hasil pengolahan data mengenahi laju estimasi jumlah penduduk di Pulau Pramuka. Dengan dengan nilai estimasi laju timbulan sampah maka dapat dihitung estimasi laju timbulan sampah pulau Pramuka sebagai terlihat pada Tabel 5 berikut ini.

Tabel 5. Estimasi Laju Timbulan sampah P Pramuka

\begin{tabular}{ccccc}
\hline No & Tahun & $\begin{array}{c}\text { Estimasi Jumlah } \\
\text { Penduduk } \\
\text { (orang) }\end{array}$ & $\begin{array}{c}\text { Laju Timbulan } \\
\text { Sampah } \\
(\boldsymbol{\%})\end{array}$ & $\begin{array}{c}\text { Estimasi laju } \\
\text { timbulan sampah } \\
(\%)\end{array}$ \\
\hline 1 & 2011 & 942 & & $1,592.50$ \\
2 & 2012 & 1,064 & & $1,799.53$ \\
3 & 2013 & 1,203 & & $2,033.46$ \\
4 & 2014 & 1,359 & & $2,297.81$ \\
5 & 2015 & 1,536 & & $2,596.53$ \\
6 & 2016 & 1,736 & & $2,934.08$ \\
7 & 2017 & 2,048 & & $3,462.21$ \\
8 & 2018 & 2,417 & & $4,085.41$ \\
9 & 2019 & 2,852 & & $4,820.78$ \\
10 & 2020 & 3,365 & & $5,688.53$ \\
11 & 2021 & 3,971 & & $6,712.46$ \\
12 & 2022 & 4,685 & & $7,920.70$ \\
13 & 2023 & 5,529 & & $9,346.43$ \\
14 & 2024 & 6,524 & & $11,028.79$ \\
15 & 2025 & 7,698 & & $13,013.97$ \\
\hline
\end{tabular}

Sumber: hasil olahan peneliti

\section{KESIMPULAN}

Berdasarkan temuan lapangan dan analisis disimpulkan bahwa kualitas hidup yang terkait dengan masalah sampah yang dirasakan oleh warga adalah sebagian besar sampah yang dihasilkan oleh warga tidak berakhir di Lokasi Pembuangan Sampah (LPS) melainkan di urukan, laut dan lingkungan rumah. Faktor modal sosial yang mempengaruhi faktor predisposisi dan faktor penguat. Faktor finansial tidak adanya anggaran dari kelurahan dan masyarakat. Faktor teknologi, tidak termanfaatkannya mesin pembakar sampah/incinerator Faktor ini disebut sebagai berikut; banyak masyarakat RW 01 yang mereklamasi (menguruk) pantai dengan batu dan sampah untuk tempat tinggal mereka. Faktor ini disebut sebagai faktor lingkungan. Jauhnya jarak antara LPS dan rumah warga membuat warga tidak membuang sampah rumah tangga mereka ke LPS. Faktor ini disebut sebagai faktor fisik. Seringnya program-program atau kegiatan-kegiatan yang melibatkan masyarakat Pulau Pramuka membiasakan memberikan uang atau amplop ke masyarakat. Faktor program Belum adanya program pengelolaan sampah secara menyeluruh dan 
terpadu. Faktor ini disebut sebagai modal fisik yang terkait dengan masalah sampah yang dirasakan oleh warga dan faktor-faktor yang mempengaruhinya, serta aset yang dimiliki warga RW Pulau Pramuka maka diusulkan program pengelolaan yaitu Program Membuang Sampah pada Tempatnya, Program Sadar Sampah untuk meningkatkan rasa tanggungjawab warga terhadap masalah sampah, Program Pemilahan Sampah, karena mengingat masih $95 \%$ warga yang tidak melakukan pemilahan antara sampah organik dan sampah non organik pada saat diwadahi di tempat sampah, dan Program Pengangkutan Sampah, yang menjadi salah satu faktor yang menyebabkan masalah sampah di RW karena tidak berjalannya lagi petugas pengangkut sampah RW karena gaji yang tidak lancar. Serta Program Peningkatan Kerjasama diantara pengurus RT, RW, LMK dan Kelurahan dalam menangani masalah sampah dan Program Pemanfaatan Sampah Plastik, karena mengingat hanya 5\% warga RW 01 yang memanfaatkan sampah plastik untuk kerajinan tangan, padahal sebagian besar sampah yang dihasilkan oleh warga adalah sampah plastik.

\section{DAFTAR PUSTAKA}

[1]. Damanhuri, E. 2006. Preliminary identification of E-waste flows in Indonesia and its hazard characteristics. The 3rd annual conference of The National Institute of Environmental Studies. Japan.

[2]. Dainur, 1995. Materi-materi Pokok Ilmu Kesehatan Masyarakat, Penerbit Widya Medika, Jakarta.1995.

[3]. Soemirat Slamet, (2009). Jenis Dan Karakteristik Sampah. Jogjakarta.

[4]. Amos Noelaka (2008), Jenis, Sumber dan Karakteristik Sampah Rumah Tangga, Engenering, London.

[5]. Agung Suprihatin, Dwi Prihanto, Michel Gelbert. 1996. Pengolahan Sampah. MALANG: PPPGT/VEDC Malang.

[6]. Notoatmodjo, Soekidjo, 2003, Pengembangan Sumber Daya Manusia, Jakarta: PT. Rineka Cipta.

[7]. Mukono HJ. Prinsip Dasar Kesehatan Lingkungan Surabaya: Airlangga University Press; 2006. 